\title{
Immunological Analytical Techniques for Cosmetics Quality Control and Process Monitoring
}

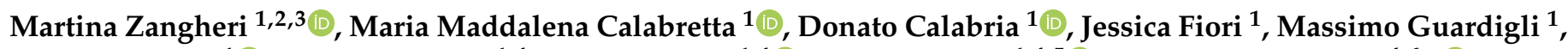

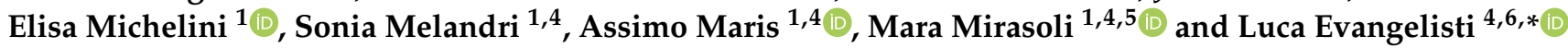

1 Department of Chemistry "Giacomo Ciamician", Alma Mater Studiorum-University of Bologna, Via Francesco Selmi 2, I-40126 Bologna, Italy; martina.zangheri2@unibo.it (M.Z.); maria.calabretta2@unibo.it (M.M.C.); donato.calabria2@unibo.it (D.C.); jessica.fiori@unibo.it (J.F.); massimo.guardigli@unibo.it (M.G.); elisa.michelini8@unibo.it (E.M.); sonia.melandri@unibo.it (S.M.); assimo.maris@unibo.it (A.M.); mara.mirasoli@unibo.it (M.M.)

2 Interdepartmental Centre for Industrial Agrofood Research (CIRI Agrofood), Alma Mater Studiorum-University of Bologna, Via Quinto Bucci 336, I-47521 Cesena, Italy

3 Interdepartmental Centre for Industrial Research in Advanced Mechanical Engineering Applications and Materials Technology (CIRI MAM), Alma Mater Studiorum-University of Bologna, Viale Risorgimento 2, I-40136 Bologna, Italy

4 Interdepartmental Centre for Industrial Aerospace Research (CIRI Aerospace), Alma Mater Studiorum-University of Bologna, Via Baldassarre Canaccini 12, I-47121 Forlì, Italy

5 Interdepartmental Centre for Industrial Research in Renewable Resources, Environment, Sea and Energy (CIRI FRAME), Alma Mater Studiorum-University of Bologna, Via Sant'Alberto 163, I-48123 Ravenna, Italy

check for updates

Citation: Zangheri, M.; Calabretta, M.M.; Calabria, D.; Fiori, J.; Guardigli, M.; Michelini, E.; Melandri, S.; Maris, A.; Mirasoli, M.; Evangelisti, L. Immunological Analytical Techniques for Cosmetics Quality Control and Process Monitoring. Processes 2021, 9 , 1982. https://doi.org/10.3390/ pr9111982

Academic Editor: Alina Pyka-Pajak

Received: 3 September 2021

Accepted: 4 November 2021

Published: 6 November 2021

Publisher's Note: MDPI stays neutral with regard to jurisdictional claims in published maps and institutional affiliations.

Copyright: (c) 2021 by the authors. Licensee MDPI, Basel, Switzerland. This article is an open access article distributed under the terms and conditions of the Creative Commons Attribution (CC BY) license (https:/ / creativecommons.org/licenses/by/ $4.0 /)$.
6 Department of Chemistry “Giacomo Ciamician”, Alma Mater Studiorum-University of Bologna, Via Sant'Alberto 163, I-48123 Ravenna, Italy

* Correspondence: luca.evangelisti6@unibo.it

Abstract: Cosmetics analysis represents a rapidly expanding field of analytical chemistry as new cosmetic formulations are increasingly in demand on the market and the ingredients required for their production are constantly evolving. Each country applies strict legislation regarding substances in the final product that must be prohibited or regulated. To verify the compliance of cosmetics with current regulations, official analytical methods are available to reveal and quantitatively determine the analytes of interest. However, since ingredients, and the lists of regulated/prohibited substances, rapidly change, dedicated analytical methods must be developed ad hoc to fulfill the new requirements. Research focuses on finding innovative techniques that allow a rapid, inexpensive, and sensitive detection of the target analytes in cosmetics. Among the different methods proposed, immunological techniques are gaining interest, as they make it possible to carry out low-cost analyses on raw materials and finished products in a relatively short time. Indeed, immunoassays are based on the specific and selective antibody/antigen reaction, and they have been extensively applied for clinical diagnostic, alimentary quality control and environmental security purposes, and even for routine analysis. Since the complexity and variability of the matrices, as well as the great variety of compounds present in cosmetics, are analogous with those from food sources, immunological methods could also be applied successfully in this field. Indeed, this would provide a valid approach for the monitoring of industrial production chains even in developing countries, which are currently the greatest producers of cosmetics and the major exporters of raw materials. This review aims to highlight the immunological techniques proposed for cosmetics analysis, focusing on the detection of prohibited/regulated compounds, bacteria and toxins, and allergenic substances, and the identification of counterfeits.

Keywords: immunoassay; cosmetics; lateral flow immunoassay; ELISA; allergen; toxins; bacteria 


\section{Introduction}

Cosmetics are among the most strictly regulated and fast-moving consumer products. The regulation of cosmetic products, aimed at ensuring their safety and efficacy, depends both on the type of cosmetics concerned and the country of distribution [1]. Though the testing regimen imposed differs among countries, the key elements assessed include the substantiation of their claims, their shelf-stability, as well as the levels of harmful compounds and microbes present in product batches. There are two instrumental analytical techniques that are considered to be the "gold standard" as they provide the best performance in terms of sensitivity, accuracy, and specificity. These are chromatographic methods (such as HPLC or GC) and mass spectrometry [2]. Spectrophotometric methods (Raman, IR, NIR, and UV-Vis) are also widespread in the characterization of cosmetic products [3]. Standard protocols reported by current regulations of the different countries are applied, which are determined on the kind of sample and on the target analyte of interest [4]. These approved analytical methods do not fully cover the wide range of target analytes that represent prohibited or restricted cosmetic ingredients by different legislations. Indeed, it is essential to ensure that the quantities of ingredients present in the various batches of finished products that are marketed corresponds exactly to the designed formulation and does not exceed the authorized content [3]. Moreover, the cosmetic industry market has shown rapid growth on a global level in recent years. This means that the development of quality control methods that are rapid and low-cost yet still efficient is a priority [4].

In the specific case of cosmetics analysis, there are some features that must be considered. First, cosmetic samples have very complex and diverse matrices since they contain a large number of components in a variety of different formulations. Therefore, cosmetic products most often demand considerable preanalytical treatments, such as solubilization, extraction, preconcentration, or purification. Occasionally, strong acid or alkaline digestion are essential. In some other cases, different types of reactions, such as hydrolysis, saponification, or even redox, may be needed. This aspect could be considerably simplified thanks to the use of highly selective and specific analytical methods that would provide target analyte detection even within very complex matrices with no or minimal sample pre-treatment. Indeed, in recent years, the trends have shifted towards the development of simple, sustainable, and environmentally friendly methodologies by applying liquidbased and ultrasound-assisted extraction technologies to obtain a high analyte enrichment, avoiding the use of organic solvents. This option makes is possible not only to work with green and sustainable procedures but also to exploit non-organic solvents that are compatible with the application of bioanalytical methods based on the use of biospecific probes. In particular, Celeiro et al. reported on the most innovative techniques used for the sample pre-treatment and for the analyte extraction in cosmetic products based on nonorganic solvents, which are suitable for performing the analysis on-site with easy-to-use instrumentation [5].

Other features that are strongly recommended for cosmetics analysis are multiplexing, i.e., the ability to determine several analytes simultaneously through a single analysis, and a high sensitivity for the detection of forbidden or regulated substances down to very small traces. Furthermore, high productivity is required for the rapid processing of many samples; therefore, the method should be simple, rapid, and characterized by a high level of automation. Lastly, the environmental impact of the analytical procedure should be limited, and thus, methods should consume no or limited amounts of organic solvents and toxic reagents.

A large number of research articles have reported novel analytical procedures for the detection of a wide range of target analytes in cosmetics. In many cases, innovative approaches based on well-established instrumental techniques were reported, such as chromatography, electrophoresis, molecular spectroscopy, electrochemistry, and atomic spectroscopy [2,3]. Recently, immunoassays have been successfully commercialized and widely employed in the detection and quantification of prohibited or restricted ingredients in the food industry $[6,7]$. Considering the increasing danger related to cosmetic safety, the 
immunological techniques could be an interesting, as well as easier and faster, alternative to provide supervision and control with regard to the presence of harmful additives or species, which would be appropriate for a large number of samples. Immunoassays refer to a set of analytical methods based on specific antigen-antibody interactions. This specificity makes immunoassays valid candidates in the field of cosmetics analysis as they enable the detection of small traces of analytes even within very complex matrices [8]. Furthermore, by using specific antibodies for different compounds, it is also possible to detect several species simultaneously, thus fulfilling the multiplexing requirement. Another advantage offered by immunological methods is the great ease-of-use and rapidity of the tests, which can be carried out in a few hours, combined with the possibility of being completely automated. Finally, immunoassays are in line with the green analytical chemistry principles, as they are conducted in aqueous environments and do not employ organic solvents, nor do they use toxic chemicals. The main limitation of immunological assays is related to their sensitivity. Indeed, the limit of detection and quantification achievable by these methods is not comparable with those offered by traditional reference techniques such as mass spectrometry, HPLC, and GC. Furthermore, the cross-reactivity phenomenon can cause a lack of specificity since it involves the recognition, by the antibody, not only of its specific antigen but also of the analogue species. However, immunoassays could be proposed as screening methods to be applied in series on a great number of samples in order to identify suspicious batches that will need to be subjected to further analysis.

Immunoassays can be performed in two different configurations, namely the noncompetitive or sandwich configuration (useful for the detection of macromolecules, such as pathogens, bacteria, and allergen proteins) and the competitive configuration (used for the detection of small molecules, such as antibiotics, pesticides, mycotoxins, etc.). Moreover, immunoassays can be based on a variety of detection principles, mainly optical or electrochemical, depending on the type of label employed. Conventional labels (such as enzymes, colloidal gold, and fluorescent nanoparticles) are conjugated to antibodies or antigens to assemble probes. The intensity of the signal from the probes could indicate the amount of the targets after the probes interact specifically with the targets in the designed sample. Immunoassay-based methods that are routinely used in clinical-diagnostic analyses exploit the Enzyme-Linked ImmunoSorbent Assay (ELISA) format. It makes use of an enzyme (among the most used are alkaline phosphatase (ALP), horseradish peroxidase (HRP), or glucose oxidase (GOD)) as a label in order to catalyze a reaction in the presence of a specific enzyme substrate, thus producing a measurable signal that is employed for quantitative detection of the target analyte. Depending on the nature of the enzymatic substrate, it is possible to exploit different detection principles (e.g., colorimetric, chemiluminescent, or electrochemiluminescent detection). Generally, these methods are based on the use of bench-top laboratory equipment by specialized personnel. In particular, the assay is performed in a microwell plate platform, and it requires a multistep procedure that takes a few hours to be completed. Indeed, the addition of the sample and of the immunoreagents require incubation times generally ranging from 30 to $120 \mathrm{~min}$ depending on the application, and they are followed by several washing steps. Finally, the addition of the enzymatic substrate allows the development of the analytical signal, and the measurement can be performed exploiting a multiwell plate reader (Figure 1(top line)). 


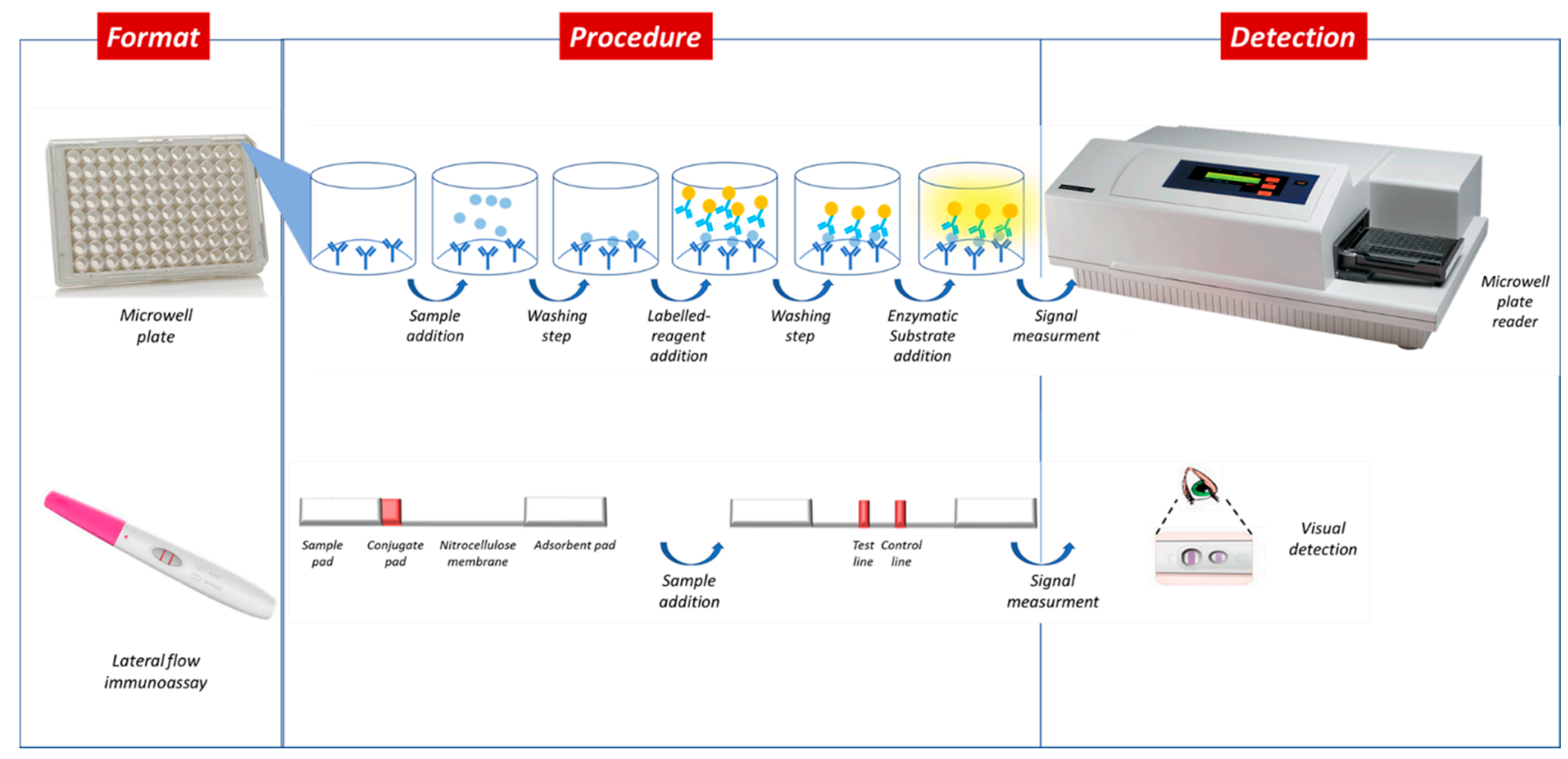

Figure 1. Scheme of the major differences among the conventional immunoassay format approaches based on bench-top instrumentation used in an equipped laboratory setting (top line) and a rapid and portable platform exploiting the LFIA principle for on-site applications (bottom line).

Another very standard format for the immunoassay is the so-called LFIA, which stands for Lateral Flow ImmunoAssay technique. In LFIAs, the immunoassay is performed on nitrocellulose membrane. The immunoreagents are immobilized in determined positions, while other reagents are carried along the strip by the flow, which is driven by capillary forces established upon sample addition. At the beginning, LFIAs were employed as rapid qualitative tests, appropriate for detecting, using a colorimetric-based visual approach, whether a target analyte in the sample was present or absent. Indeed, the most common detection principle is based on the use of bioreagents labelled with colloidal gold or latex particles. Due to label accumulation in specific positions along the strip, colored bands form and are visually detected to provide a "yes/no" response regarding the presence of analytes. Specifically, the analytical response is checked in the so-called Test line (defined as the T-line), whilst the presence of a second Control line (defined as the C-line) provides confirmation of the correct performance of the test and the reliability of the results [9]. This platform has gained great success and has been widely exploited for routine applications (e.g., pregnancy tests) thanks to its simplicity and, consequently, its low cost (bottom line). Significant improvements and remarkable results have been obtained through the implementation of different labels and through coupling with sensitive detectors, which are also portable and easy to use, that have allowed the development of ultra-sensitive quantitative LFIAs [10].

As an alternative, label-free optical immunosensors represent an emerging, simple, and sensitive technology for the development of easy-to-use analytical devices. In this context, surface plasmon resonance (SPR) detection is based on the refractive index sensor changes when in the proximity of the surfaces of noble metal nanostructures. The principle for biosensing applications refers to the possibility of quantifying the shifts in the SPR extinction wavelength maximum, due to the dependence of the modified interface refractive index, caused by biorecognition events on the surface. The great advances in these technologies have led to the development of miniaturized SPR instrumentation for immunosensor-based analysis.

Figure 2 summarizes the major peculiarities of immunoassays and the key points on which researchers act to improve their performance and implement their applicability. 


\section{SPECIFICITY}

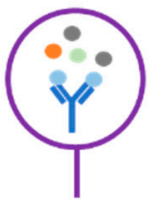

Recognition of the target analyte in complex matrices
EASE OF USE

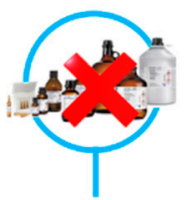

No need of complex sample pre-treatment

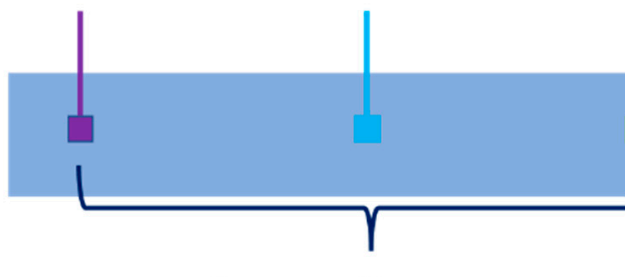

Features of immunoassays

MULTIPLEX

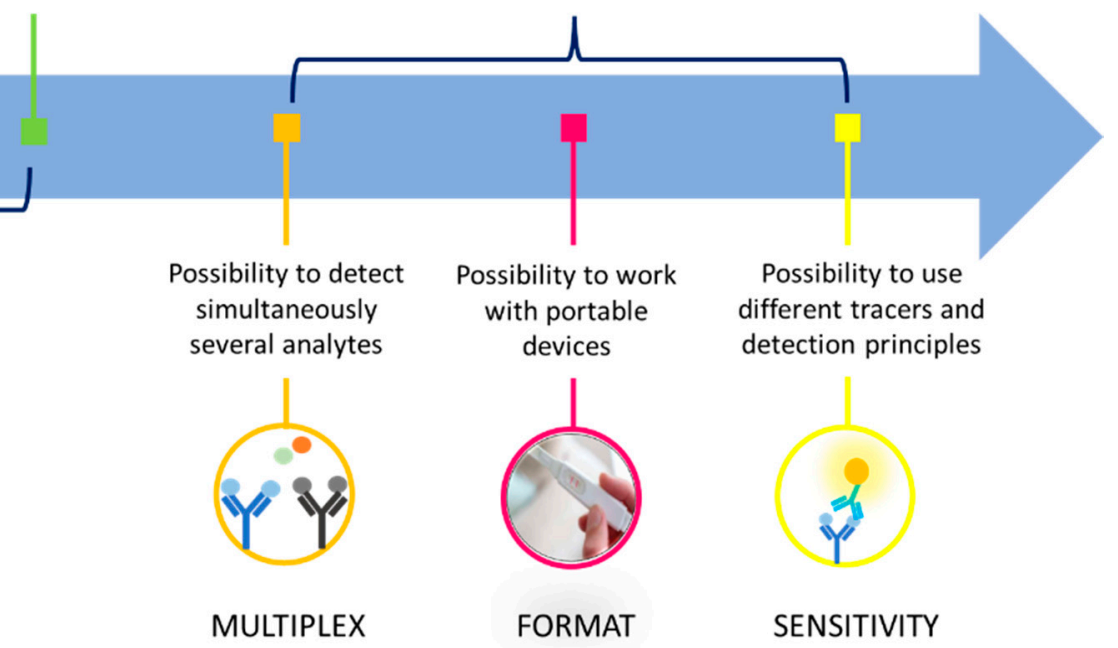

Immunoassays can require from few minutes to few hours
Improving immunoassay applicability

Figure 2. Scheme of the major peculiarities of immunoassays and the key points on which researchers act to improve their performance and implement their applicability.

The objectives of this review are to show the major recent achievements in the field of immunoassays applied to cosmetics analysis, focusing on the detection and quantification of harmful species that are restricted or even prohibited by legislation, and on the possibilities for their future applications in large-scale quality control during production processes.

The review is structured as follows. In Section 2, we discuss the detection of common allergens in cosmetics and personal care products. In Section 3, we provide the reader with information about the detection of prohibited and restricted cosmetic ingredients following different regulations. In Section 4, we report the works dedicated to the detection of typical toxins, bacteria and antibiotics in cosmetics and personal care products. Finally, we conclude the work in Section 5 with a discussion about the detection of markers that are indicative of counterfeiting.

\section{Detection of Allergens in Cosmetics}

The United States Food and Drug Administration (FDA) has compiled a list of common allergens found in some cosmetics and personal care products and the EU Regulation $1223 / 2009$ lists allergens in the prohibited or restricted ingredients. Allergens can be classified into five classes, i.e., natural rubber, fragrances, preservatives, dyes, and metals [11]. The typical approach for detecting allergens in cosmetics is GC coupled with MS or MS/MS [12-17]. In a few cases, HPLC-DAD has been used for the detection of allergenic substances in cosmetics, and an example was reported by Perez-Outerail et al. [18].

Immunological techniques are routinely used for detecting allergens in foodstuff and several immunological methods have been proposed in the literature [19-21] or are available as commercial kits for monitoring the production chain in the food industry [22-24]. Nowadays, many cosmetics are characterized by formulations that include substances derived from food (e.g., fruits, dried fruits, oats, protein substances of animal origin, etc.). Therefore, the allergens found in foods can also often be present in cosmetics and personal care products that include these ingredients. Immunological assays that are already available for the detection of allergens in foodstuff can be converted in order to recog- 
nize the same target analytes in cosmetics, optimizing specific procedures for the sample pre-treatment. Indeed, several works reported in the literature show the development of immunological methods that can be performed on both food and cosmetic matrices. Duffort et al. reported on the development of a non-competitive ELISA method for the quantification of the leading peach allergen (Pru p 3), which is a lipid transfer protein (LTP) [25]. The assay involved the use of microwell plates in which anti-Pru p $3 \mathrm{mAb}$ monoclonal antibodies were immobilized at the bottom of the microwells and the detection was performed, after the incubation with the sample, using anti-Pru p 3 rabbit serum and goat anti-rabbit IgG antibodies conjugated with peroxidase and by adding the proper colorimetric substrate. The assay was applied to analyze the presence of this allergen in food and cosmetics (shampoo, air-freshener, toothpaste, and soap) containing processed peach as well as in several fresh fruit batches. The proposed ELISA allowed the detection of Pru p 3 with very high sensitivity since $0.1 \mathrm{ng} / \mathrm{mL}$ concentration levels of ppb were achieved, which makes it extremely useful in the standardization of peach extracts. This makes it possible to measure the allergen content of the extract used in cosmetic formulations or in the preparation of foodstuffs.

Hidden food allergens are a problem of great importance both for the food and cosmetics industry and for the allergic consumer. A label-free immunosensor based on surface plasmon resonance (SPR) was proposed by Ashley for quantifying milk allergens. The $\beta$-lactoglobulin (BLG) protein represents an important fraction among milk proteins and it could be used as a marker for monitoring the amount of milk; furthermore, its detection can be employed to control implants in final rinse samples of the cleaning-inplace (CIP) systems of food and cosmetic producers [26]. The detection principle based on SPR offers distinct features, such as the possibility of being implemented into an automated, adaptable, and multipurpose platform to provide real time analysis. The proposed device also makes it possible to directly analyze several samples, on-line or at-line, without compromising in terms of its high sensitivity. Indeed, the obtained limit of detection (LoD), $0.16 \mu \mathrm{g} / \mathrm{mL}$, is perfectly adequate for detecting the maximum allowed amount of $\beta$-lactoglobulin, which is $2 \mu \mathrm{g} / \mathrm{mL}$. The proposed SPR-based immunosensor offers many advantages comprising label-free detection, real-time analyses, and the possibility to have an integrated on-line approach and a higher sensitivity with respect to ELISA-based methods. Thus, this biosensor can be evaluated as a powerful analytical tool for monitoring the contamination with BLG in several production processes that are necessary for food, medicinal and cosmetic products, and it could be used in industry for managing the safety risks related to milk allergen.

Gluten, another substance that can be present in cosmetics as well as in foodstuff, is responsible for celiac disease (CD) and is also related to wheat allergies [27-30]. The "gluten-free" regulation, issued by the U.S. Food and Drug Administration in 2013, aims to provide safe food choices for celiac people. Cosmetic products are not subjected to this final rule, meaning that analytical methods for gluten detection in cosmetics are guaranteed to help celiac or allergic people in evaluating their safety. Sharma et al. [31] analyzed 36 cosmetic products for measuring gluten content using three different ELISAs (two non-competitive tests based on the sandwich format, and one with a competitive format). The estimated quantity of gluten in the cosmetic samples identified as gluten-free was below the LOQ of the ELISA kits employed. However, the reliability of ELISA depends on the investigated cosmetic sample, and the method requires a specific matrix-related validation for an accurate gluten analysis. The study of a great number of samples coming from different types of cosmetics is necessary for evaluating the suitable conditions for the quantification of gluten in the complex matrices of personal care products. Moreover, studies for assessing the dermal penetration of gluten from cosmetics are also necessary to understand the potential risks related to dermal exposure to gluten for people who suffer from CD. In this context, Tranquet et al. raised the question of diversification in terms of the presence of gluten in both the food and cosmetics industries, which is obtained by deamidation, leading to the production of water-soluble gluten. Current 
analytical techniques for gluten detection are not suitable for detecting deamidated gluten. Therefore, the authors produced and compared different monoclonal antibodies (mAbs) for developing a competitive indirect colorimetric ELISA to precisely quantify deamidated gluten [32]. The selected mAb allowed the development of an ELISA method characterized by high selectivity (the IC50, defined as the analyte concentration that caused $50 \%$ inhibition of antibody binding, corresponded to $85 \mathrm{ng} / \mathrm{mL}$ ) and a detection limit corresponding to $25 \mathrm{ng} / \mathrm{mL}$.

Immunological methods for the detection of allergens are already widespread in the food field, have received a great deal of interest over time, and have been applied in routine control applications. Since many food allergens can also be found in cosmetic matrices, these methods can also be considered very promising in the cosmetic field, allowing even very complex matrices to be analyzed quickly and exploiting a low-cost instrumentation.

\section{Detection of Prohibited and Restricted Cosmetic Ingredients}

The safety of cosmetic products is related to the safety of their ingredients. Many countries have developed their own regulatory lists of banned or restricted cosmetic ingredients. The regulation (EC) 1223/2009 regarding cosmetic products (EU Cosmetics Regulation) is the main regulatory framework for finished cosmetic products placed on the European market [33]. The list of banned components, which are not allowed to be employed in cosmetic products, is shown in annex II of the EU Cosmetics Regulation, while annex III of the EU Cosmetics Regulation includes the list of restricted substances. They are allowed to be used even if their use must comply with corresponding use conditions (i.e., content limit, use scope). The detection of these compounds is important for the industries that have to check the product quality of cosmetics, ensuring their safety and protecting the consumers' health [34]. Among substances that may harm the consumer, steroids represent prohibited components in cosmetics since they can affect the biological processes in humans even at a very low level. Many works proposed the use of immunoassays for the detection of several steroids in clinical [35], environmental [36], and food [37] applications. Recently, they have also been applied to the cosmetics field and several examples can be found in the literature. Wang et al. proposed a rapid immunoassay for the detection of the illegal addition of dexamethasone (DE) in cosmetics [38]. Indeed, DE is a synthetically obtained glucocorticoid, which is often added to cosmetic products (i.e., facial masks), thanks to its advantageous short-term effects, but, according to the Safety and Technical Standards for Cosmetics (no.268, 2015), issued by the Chinese National Medical Products Administration [39], and to the European regulation 1223/2009 [40], glucocorticoids are prohibited from being used as components or raw materials in cosmetics. The authors developed a highly selective monoclonal antibody for application in a competitive colloidal-gold-based LFIA method that made it possible to rapidly determine DE contents at concentrations between 100 and $200 \mathrm{ng} / \mathrm{mL}$ in commercial facial masks. Another work was reported by Zhang et al., [41] for the quantification of triamcinolone acetonide (TCA), which is a potent and long-action glucocorticoid often employed in the pharmacological therapy of several pathological conditions [42]. This component is often illegally added to cosmetic and personal care products [43] since it is able to decrease inflammation and can momentarily alleviate the symptoms of inflammatory skin problems. TCA in cosmetic samples was analyzed using different analytical methods, which were mostly based on liquid chromatography and mass spectrometry [43-47]. The authors proposed a LFIA method for the quantification of TCA by exploiting a probe based on the up-conversion of luminescence nanoparticles. Employing this detection principle, they obtained a dynamic linear range between 1 and $100 \mathrm{ng} / \mathrm{mL}$ and an LoD corresponding to $20 \mu \mathrm{g} / \mathrm{kg}$ in cosmetic samples (Figure 3). 

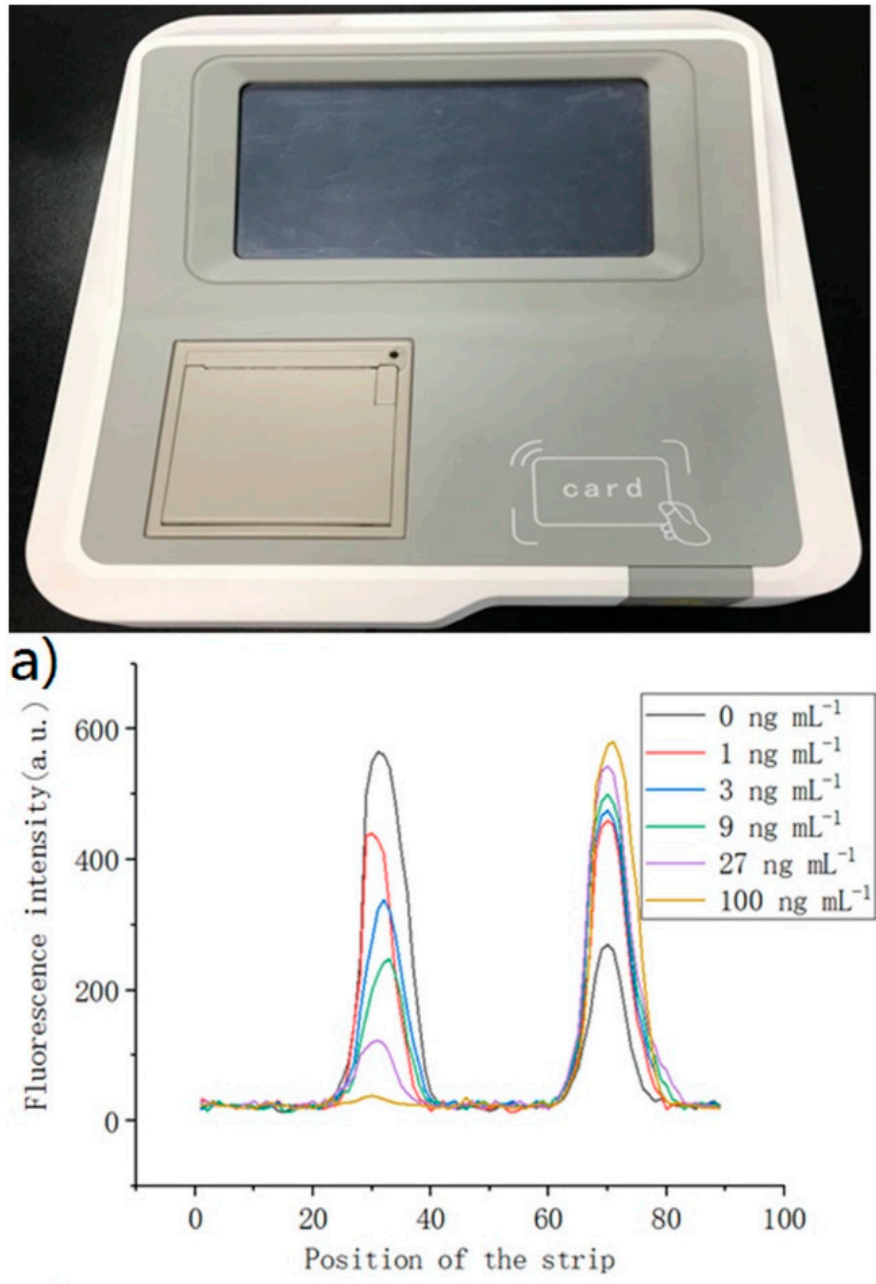

c)

Figure 3. (a) The compact reader used for the detection of luminescent up-conversion nanoparticles. (b) The UCNPs-ICA at different TCA levels measured using a fluorescence camera. (c) Peaks of UCNPs-ICA at different TCA concentrations measured exploiting a luminescent up-conversion detector. The signal is expressed in terms of fluorescence intensity with respect to the position along the strip; thus, the peaks are relative to the areas corresponding to the $\mathrm{T}$ line (first peak) and the C line (second peak). (d) Calibration curve determined for the UCNPs-ICA, with different concentrations of TCA. Each value is calculated as the mean of 3 replicates. Reprinted from Ref. [41], copyright 2019, with permission from Elsevier.

Another category that has been ruled is that of phthalates, which are the esters of phthalic acid, and they can be found as ingredients or as contaminants in cosmetic and personal care products. Their presence as contaminants can be ascribed to the manufacturing procedure, to the starting materials, or to the migration of phthalates from polymeric packaging materials (polyvinyl chloride-PVC). Eight phthalates (DBP, DEHP, BBP, DMEP, DnPP, DiPP, DPP, and DiBP), classified as H360 or H361, are not allowed in cosmetics according to the European regulation 1223/2009 [40]. A great number of immunoassays have been reported in the literature for the detection of different phthalates in food and in environmental matrices [48-56]. In cosmetics, the most used methods for the detection of phthalates are based on liquid chromatography $[57,58]$. Wei et al. proposed an indirect competitive ELISA for the detection of DBP, and the technique was used to assess the presence of this target analyte in nail polish samples [59].

Inorganic harmful substances could also be found in cosmetics, mainly metal cations, such as chromium, lead, cadmium, mercury, nickel, manganese, and thallium. Immunoassays for the analysis of heavy metals are rapidly gaining importance and several works have reported their applications [60-65]. This trend is also confirmed in the field of 
cosmetics analysis, where some examples have been reported for the detection of mercury. The maximum concentration of mercury in ready-to-use products must not exceed $0.007 \% \mathrm{~m} / \mathrm{m}$ [40]. Wang et al. [66], developed an indirect competitive ELISA method for the detection of mercury(II) ion, which was successfully tested on several kinds of samples including facial cleanser and night creams. Zhang et al., [67] proposed a quick and sensitive electrochemiluminescent (ECL) competitive immunoassay for the determination of mercury(II) ion. The competitive immunoassay was based on the use of CdSe quantum dots (QDs)-labeled monoclonal antibodies (mAbs) that were specific for mercury(II), and of methylmercury-6-mercaptonicotinic acid-ovalbumin as a coating antigen. Mercury(II) ions in the sample competed with the coating antigen for binding to QD-labeled $\mathrm{mAb}$, thus producing a decreasing ECL signal with the increasing of the concentration of mercury(II) in the sample. The method, which enabled the detection of mercury(II) in a range between 0.02 and $100 \mathrm{ng} / \mathrm{mL}$, displayed an LoD of $6.2 \mathrm{pg} / \mathrm{mL}$ and was tested on hand cream.

The application of immunoassays to the detection of prohibited ingredients is linked to the sensitivity that can be achieved through these techniques. Indeed, these substances should be completely absent or present in very small traces in the finished cosmetic product. This implies the need for ultra-sensitive methods that must be competitive with traditional chromatographic techniques that are coupled with mass spectrometry. For this reason, an interesting prospect in terms of the application of immunological techniques may be that of applying innovative tracers that will allow the development of highly sensitive systems characterized by high detectability and very low detection limits.

\section{Detection of Toxins, Bacteria, and Antibiotics}

Even if cosmetic products must not be completely aseptic, the possibility of such a product containing a microbiological contamination could represent a serious risk and cause a spoilage of the product, leading to a serious risk to the health of consumers [68-71]. This contamination can occur during the production or the packaging step of the cosmetic product, or during its use by the consumer. As it concerns the production and packaging stages, the manufacturers have the responsibility to ensure suitable microbial preservation and to guarantee the level of the product's quality as envisaged in its specification. Regarding the use of the product, the consumer must preserve its safety, paying special attention to store it in suitable conditions. Over the last decades, the actuation of Good Manufacturing Practices [72] has been the basis for increasing the quality of industrial control analyses. To this end, several techniques for the quantification of the total microbial content of bacteria, yeasts, and molds were provided by the United States Pharmacopoeia (USP) Microbial Limits Test [73]. In detail, it outlines four bacteria as standards (Escherichia coli, Pseudomonas aeruginosa, Salmonella spp., and Staphylococcus aureus) while the European Pharmacopoeia imposes specific analyses for determining the quantity of enterobacteria [74]. Despite these guidelines, microbial contamination still represents a leading cause of product recall worldwide, especially for those produced in developing tropical countries [75]. Several immunoassays have been reported in the literature for the detection of bacteria in foodstuffs and water [76-79]. English et al. applied a commercially available ELISA kit, which was developed for revealing Staphylococcus aureus in foodstuff and food-related samples, to cosmetic and pharmaceutical raw materials and final products [80]. Their work demonstrated that the proposed non-competitive immunological method provides a rapid and simple alternative to the standard cultural technique for the detection of Staphylococcus aureus contamination in the cosmetic and pharmaceutical fields.

In order to inhibit microbial growth, preservatives are added to cosmetics. Among them, chloramphenicol (CAP), usually employed as a wide-spectrum antibiotic characterized by a great antimicrobial activity, is also widely applied in cosmetics formulations to avoid the presence of microorganisms [81,82]. However, recent studies evidenced that amphenicol-based antibiotics can show a potential negative effect on consumer health $[83,84]$, which has led to their application being prohibited in several countries, such as Europe, the USA, and China [85-88]. Despite this, CAP is still found in cosmetics, since 
it is cheap, and it has an excellent antibacterial effect. To guarantee the safety of cosmetics, several methods of CAP detection have been proposed, mainly based on chromatography and mass spectrometry techniques [89-91]. However, these techniques are based on the use of expensive instrumentations, long and difficult pretreatment protocols, and a dedicated staff, and they are not appropriate for the quick screening of a numerous samples. For this reason, $\mathrm{Li}$ et al. [92] proposed a direct competitive and highly sensitive chemiluminescent ELISA method to monitor CAP in cosmetics (Figure 4A). The LoD was $0.0021 \mathrm{ng} / \mathrm{mL}$ and the method allowed the rapid quantitative detection of CAP in cosmetic matrices, simplifying the monitoring process used in determining the CAP contamination. Xun et al. developed a simple, low-cost and rapid competitive Multi-Dot-ELISA method for simultaneously detecting three antibiotics that are commonly abused (ciprofloxacin, tetracycline, and sulfamethoxydiazine) in order to reveal the illegal additives in cosmetics [93]. The device was based on a nitrocellulose membrane in which the different antigens were immobilized in localized areas. After the incubation with the sample and the specific antibodies labeled with HRP, by adding a colorimetric enzymatic substrate, it was possible to visually detect the formation of colored spots. The position of these spots made it possible to distinguish among the different target analytes.

Microorganisms present in the cosmetic product may also produce toxins, which are generally small molecules, peptides, or proteins that are capable of causing serious pathological conditions when they are put in contact or adsorbed by body tissues and interact with biological macromolecules, such as enzymes or cellular receptors. These species are stable in the environment and can remain in nature for a long time without degrading [94]. Botulinum neurotoxin (BoNT) produced by Clostridium botulinum is the most common cause of foodborne illness worldwide [95]. Cheng et al. proposed an immunosensor based on the use of functionalized nanoparticles that were obtained by the formation of immunocomplexes that comprised a fluorescent particle implemented with $\mathrm{Au}$ nanoparticles (AuNPs), toxic proteins, and antibodies. The diffusivity of the particle decreased with the increasing of the concentration of the target analytes [96]. This immunosensor was employed for quantifying the concentration and activity of Botulinum and was tested on two commercially available samples (BOTOX and Dysport), which are currently used in cosmetics treatment (Figure $4 \mathrm{~B}$ ). The authors also evaluated the activity of the botulinum toxin by developing an immunoassay in which synaptosomalassociated protein 25 (SNAP-25) was immobilized on fluorescent probe particles. Then, active botulinum that was present in the sample was cleaved by the SNAP-25 protein and the detection was performed using AuNP-conjugated antibodies. Thus, toxicity could be detected from slight changes in diffusivity. For the rapid detection of toxins in cosmetics, Dayan-Kenigsberg et al. proposed a competitive LFIA-based technique for detecting ricin down to $0.005 \mu \mathrm{g} / \mathrm{mL}$ [97].

Immunoassays on cosmetic matrices for the detection of antibiotics, toxins, and bacteria are not yet widespread. However, they can find very interesting applications, especially as regards the control of bacterial contamination during consumer use. In fact, generally, cosmetic products are used by the consumer over a long period of time, but, once opened, they can be a substrate for bacterial proliferation. For this, it would be useful to have simple and quick tools based on easy-to-use techniques such as LFIA that the consumer can apply directly from home to check the condition of the cosmetic before its use. 

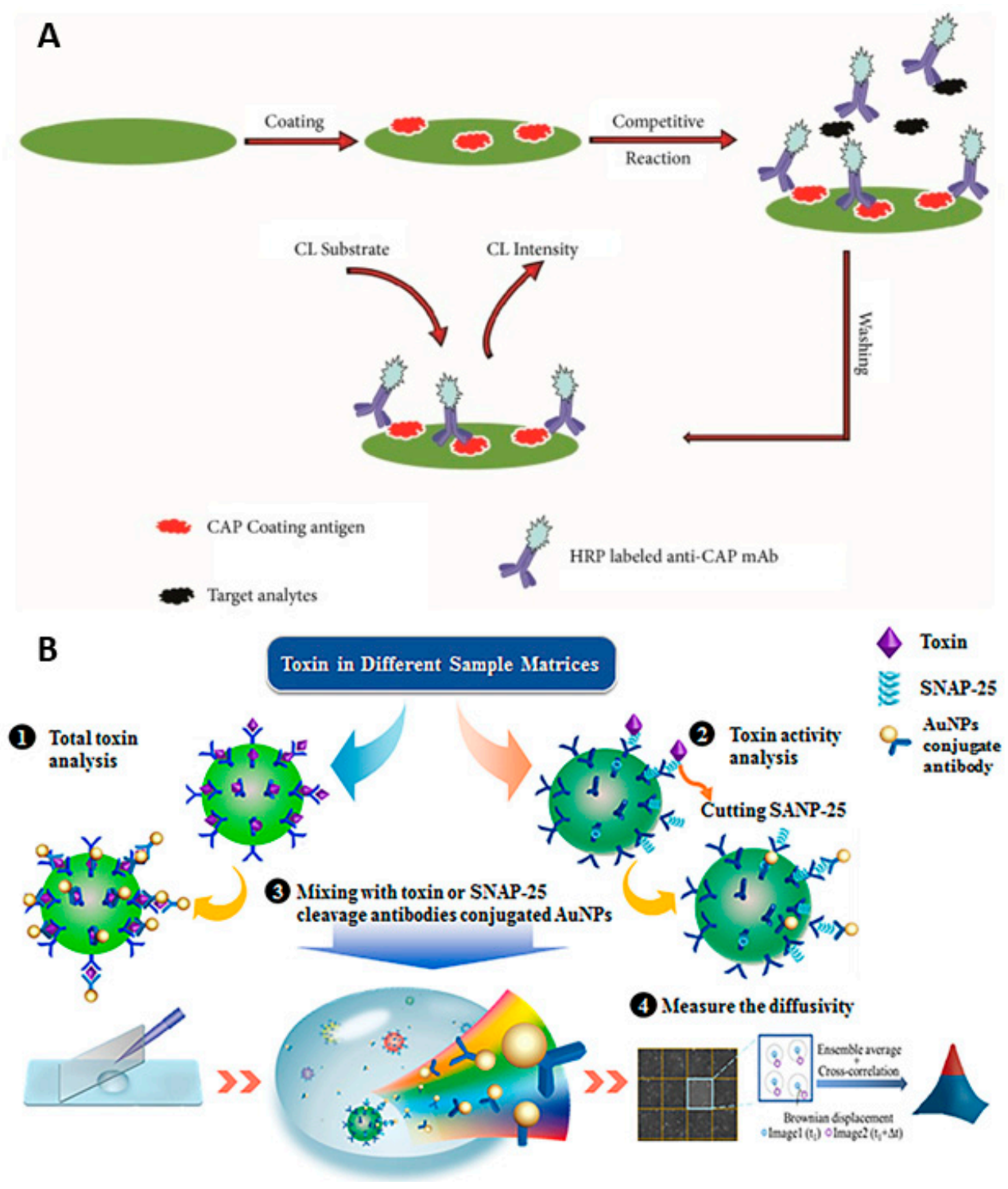

Figure 4. Panel (A): Schematic of the CL-ELISA method. Reprinted with permission from Ref [92], copyright 2019. Panel (B): Conceptual scheme of the immune-sensing platform to perform the total toxin analysis and the toxin activity analysis in different complex matrices. Steps 1 and 2: Anti-BoNT/A or SNAP-25 antibodies were linked to AuNPs. (In the picture, SANP-25 stands for SNAP-25.) Step 3: While incubating the particle with the sample that can contain the toxin of interest, antibodies conjugated with AuNPs were added, allowing the formation of the "sandwich" immunocomplex. Step 4: Toxin concentration or activity was assessed by employing an imaging-based method using a microscope and a cross-correlation algorithm to estimate the level of Brownian motion. Reprinted from Ref. [96] with permission from ACS https:/ / pubs.acs.org/doi/abs/10.1021/acssensors.9b00644 (accessed on 5 November 2021). Further permission related to the material excerpted should be directed to ACS.

\section{Detection of Marker Indicative for Counterfeiting}

Another problem that can be encountered in the field of cosmetics is the possible counterfeiting of the ingredients, which consists in blending or replacing the genuine material with other spurious, lower quality, imperfect, spoiled, or synthetic molecules that do not conform with certified standards. This inconvenience is generally due to an intentional practice aimed at attaining financial gain by partially or fully substituting an ingredient with inferior materials with morphological resemblance, or with chemicals or inert materials [98]. Several methods have been developed for assuring the identity and provenience of some ingredients, mostly based on chromatography and mass spectrome- 
try [99-103]. The techniques for the detection of counterfeiting are constantly evolving as fraudulent ingredients placed on the market become more and more numerous. Several examples of the utilization of immunoassay in cosmetics were reported for the counterfeit edible bird's nest (EBN) products. EBNs, produced from the saliva secretion of several different swiftlet species, contain glycoproteins, carbohydrates, indispensable amino acids, minerals, and some other elements [104], which are responsible for its effectiveness in terms of several aspects of human health [105-107]. The market has seen an increase in demand for EBN products and this has resulted in the addiction of economic counterfeits in order to make a greater profit. Therefore, several economic substitutes-among others, pork skin, plant-exude, fish skin, gum karaya, algae or albumen — have been commonly utilized [108]. Several analytical techniques were proposed to authenticate and assure the quality of EBN, exploiting gas chromatography, liquid chromatography, and mass spectrometry, as well as a PCR-based method [109-113]. These techniques required specialized laboratories and well-trained personnel, so, as an alternative, the ELISA approach has been proposed. Zhang et al. reported a competitive ELISA to quantify a characteristic sialoglycoprotein that is typical of EBN [114]. The obtained LoDs were 10-18 $\mu \mathrm{g} / \mathrm{g}$ depending on the different cosmetic matrices analyzed. Tukiran et al. proposed an indirect competitive ELISA method for detecting porcine gelatins, which is a common compound found in EBN that is used to increase the net weight before selling [115]. They obtained a LoD of $0.10 \mu \mathrm{g} / \mathrm{g}$, thus offering an interesting method for quality control in the EBN business. Finally, $\mathrm{Xu}$ et al. developed an LFIA device for the detection of the characteristic glycoprotein of EBN as a marker for the identification and authentication of this ingredient [116] (Figure 5). The method is a non-competitive colorimetric LFIA in which the traditional tracer, based on colloidal gold, is replaced by an innovative material composed of $\mathrm{Au} @ S i O_{2}$. The LoD was estimated as $7.02 \mathrm{ng} / \mathrm{mL}$ and, compared to instrumental techniques or even other molecular biological methods, the LFIA can give, within $30 \mathrm{~min}$, sensitive and specific detection of EBN-specific glycoproteins. Everything can be performed without the need for devices and complicated processes. The lateral flow immunoassay of EBN glycoprotein could be used for the on-site authentication and assessment of EBN quality.

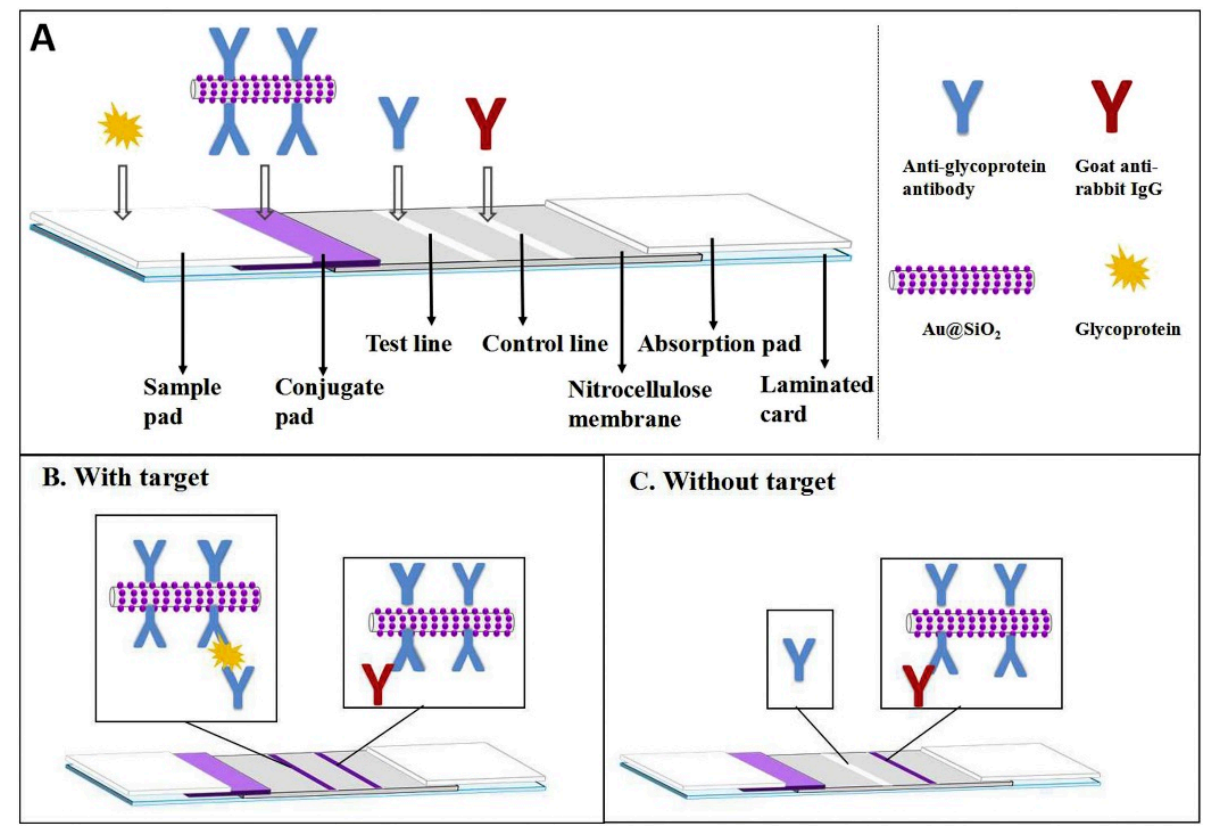

Figure 5. The operating principle for the detection of glycoprotein using the lateral flow immunoassay. (A) Sketch of the setting of the test strip. (B) illustration of the typical recognition mechanism when the molecular target is present. (C) Illustration of the recognition mechanism in cases in which the target is absent. Reprinted from Ref [116], copyright 2019, with permission from Elsevier. 
The use of immunoassays to verify the use of fake species can find significant application in the cosmetic field, as the high specificity and selectivity that characterizes the antibody-antigen bond can lead to the recognition of specific molecules, thus making it possible to distinguish them even from very similar analogues.

\section{Conclusions}

Cosmetics and the cosmetic industry constitute a field that is subject to an incredible and unstoppable growth throughout the world. The wide range of products and the complexity of their compositions represent a great challenge to the analytical chemist. Indeed, the ingredients used in cosmetic formulations, as well as the legislation applied for regulating their presence and concentrations, are continuously changing. In this context, analytical techniques that are commonly employed for quality control of cosmetic products require expensive instrumentations, well-trained personnel, and dedicated facilities. These features make the monitoring of the production chain prohibitive, especially for developing countries, which are currently the ones most involved in the production of cosmetics and in the export of raw materials. In light of these considerations, immunological techniques seem to be a perfect combination of high specificity and selectivity, which make it possible to detect target analytes in complex matrices, and ease-of-use, rapidity, and low cost. Even if, up to now, there are no examples of commercially available kits based on the application of immunological techniques in cosmetics, several methods have been proposed in the literature, exploiting different formats, such as ELISA and LFIA, and different detection principles (e.g., colorimetric, chemiluminescent, etc.) for the detection and sensitive quantification of numerous analytes of interest (Table 1). In the near future, within the field of commerce, a large increase in the diffusion of these bioanalytical tools will lead to an significant broadening of the application of immunoassays in the quality control of cosmetics, significantly reducing the costs and time associated with analysis, and thus, allowing the monitoring of the production chain from the raw materials directly to the finished products. 
Table 1. Summary of the immunological methods applied on cosmetic products proposed in the literature.

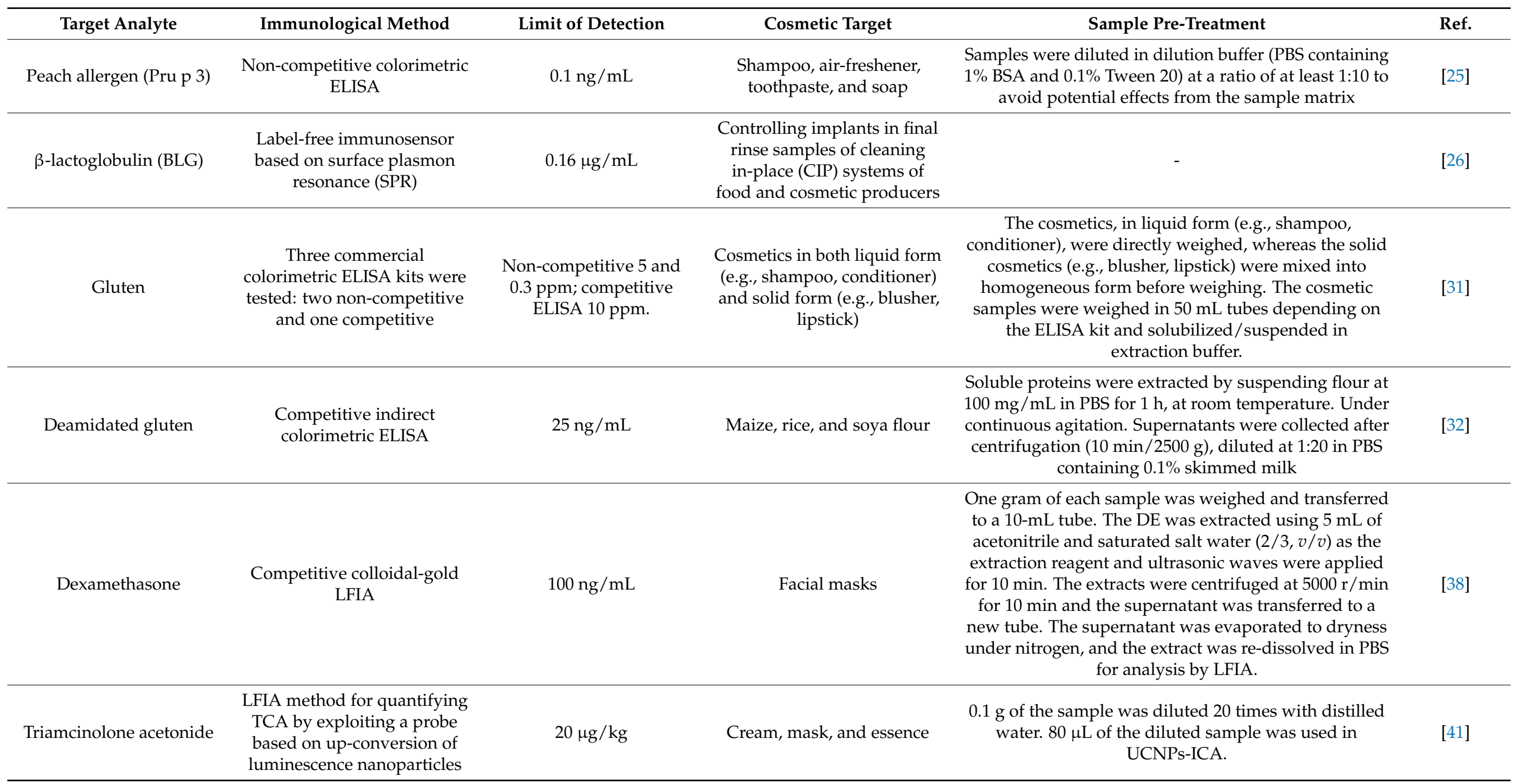


Table 1. Cont.

\begin{tabular}{|c|c|c|c|c|c|}
\hline Target Analyte & Immunological Method & Limit of Detection & Cosmetic Target & Sample Pre-Treatment & Ref. \\
\hline Phthalates dbp & $\begin{array}{l}\text { Indirect competitive } \\
\text { colorimetric ELISA }\end{array}$ & $0.426 \mathrm{ng} / \mathrm{mL}$ & Nail polish & $\begin{array}{l}\text { Nail polish was weighed at } 0.5 \mathrm{~g} \text {. After that, } 5.0 \mathrm{~mL} \text { of } \\
\text { acetonitrile was added to the nail polish } \\
\text { andultrasonically vibrated for } 30 \text { min. Another } \\
\text { extraction procedure in a stoppered glass tube was } \\
\text { carried out at room temperature overnight. The extract } \\
\text { ( } 2 \mathrm{~mL} \text { ) was evaporated using a centrifugal evaporator } \\
\text { to remove acetonitrile and then dissolved in } 2 \mathrm{~mL} \text { of } \\
\text { assay buffer (PBS containing } 0.1 \% \mathrm{BSA}) \text {. }\end{array}$ & [59] \\
\hline Mercury(II) ion & $\begin{array}{l}\text { Electrochemiluminescent } \\
\text { (ECL) competitive } \\
\text { immunoassay }\end{array}$ & $6.2 \mathrm{pg} / \mathrm{mL}$ & Hand cream & $\begin{array}{l}\text { Microwave digestion was used to extract the hand } \\
\text { cream. Briefly, } 1 \mathrm{~g} \text { of the sample was mixed with } 3.0 \mathrm{~mL} \\
\mathrm{HNO}_{3} \text { and } 2.0 \mathrm{~mL} \mathrm{H} \mathrm{H}_{2} \text { in turn. After heating at } 100 \\
{ }^{\circ} \mathrm{C} \text { for } 20 \mathrm{~min} \text {, the sample was cooled to room } \\
\text { temperature and filtered for use. }\end{array}$ & [67] \\
\hline Staphylococcus aureus & $\begin{array}{l}\text { Non-competitive colorimetric } \\
\text { ELISA }\end{array}$ & Not showed & $\begin{array}{c}\text { Irradiated Starch, } \\
\text { Simethicone, Emulsion, } \\
\text { Antiflatulent Liquid, Denture } \\
\text { Adhesive, Carboxymethyl- } \\
\text { cellulose, Medicated } \\
\text { Dentifrice, Fluoride } \\
\text { Dentifrice, Diaper Rash, } \\
\text { Ointment, Gel Dentifrice, } \\
\text { Silica }\end{array}$ & $\begin{array}{l}\text { Each sample was mixed and heated for } 15 \text { min at } 95 \mathrm{C} \text { in } \\
\text { a boiling water bath to increase lysis efficiency. }\end{array}$ & [80] \\
\hline Chloramphenicol & $\begin{array}{c}\text { Direct competitive } \\
\text { chemiluminescent ELISA }\end{array}$ & $0.0021 \mathrm{ng} / \mathrm{mL}$ & Primer lotion & $\begin{array}{l}\text { Cosmetics samples }(2.00 \mathrm{~g} \pm 0.02 \mathrm{~g}) \text { were weighed } \\
\text { precisely and transferred into } 50 \mathrm{~mL} \text { polypropylene } \\
\text { centrifuge tubes. Then, } 20 \mathrm{~mL} \text { of PBS was added and } \\
\text { vortexed for } 30 \mathrm{~s} \text {, and then ultra-sonication was } \\
\text { conducted for } 3 \text { min for the extraction of CAP. Each } \\
\text { sample was centrifuged at } 12,000 \times g \text { for } 10 \text { min at } 4{ }^{\circ} \mathrm{C} \text {, } \\
\text { and the supernatant was collected and filtered through } \\
\text { a } 0.22 \mu \mathrm{m} \text { membrane. }\end{array}$ & [92] \\
\hline
\end{tabular}


Table 1. Cont.

\begin{tabular}{|c|c|c|c|c|c|}
\hline Target Analyte & Immunological Method & Limit of Detection & Cosmetic Target & Sample Pre-Treatment & Ref. \\
\hline $\begin{array}{l}\text { ciprofloxacin, tetracycline } \\
\text { (TC) and } \\
\text { sulfamethoxydiazine } \\
\text { (SMD) }\end{array}$ & $\begin{array}{l}\text { Competitive } \\
\text { Multi-Dot-ELISA. The device } \\
\text { is based on a nitrocellulose } \\
\text { membrane in which the } \\
\text { different antigens were } \\
\text { immobilized in localized } \\
\text { areas. After the incubation } \\
\text { with the sample and the } \\
\text { specific antibodies labeled } \\
\text { with HRP, by adding a } \\
\text { colorimetric enzymatic } \\
\text { substrate, it was possible to } \\
\text { visually detect the formation } \\
\text { of colored spots. The position } \\
\text { of these spots made is } \\
\text { possible to distinguish among } \\
\text { the different target analytes }\end{array}$ & $\begin{array}{l}\text { CPFX: } 2.50 \mu \mathrm{g} / \mathrm{mL}, \mathrm{TC}: \\
2.50 \mu \mathrm{g} / \mathrm{mL} \text { SMD: } \\
1.25 \mu \mathrm{g} / \mathrm{mL}\end{array}$ & $\begin{array}{l}15 \text { commercial cosmetic } \\
\text { products were randomly } \\
\text { selected from supermarkets } \\
\text { and beauty parlors }\end{array}$ & $\begin{array}{l}\text { All samples were diluted and mixed gently with } 50 \% \\
\text { methanol and then ultrasonically oscillated for } 30 \text { min. } \\
\text { Following the centrifugation, the supernatant fluid was } \\
\text { collected for testing. }\end{array}$ & [93] \\
\hline $\begin{array}{l}\text { Botulinum neurotoxin } \\
\text { (BoNT) produced by } \\
\text { Clostridium botulinum }\end{array}$ & $\begin{array}{l}\text { Immunosensor based on the } \\
\text { use of functionalized } \\
\text { fluorescent nanoparticles } \\
\text { conjugated to anti- BoNT } \\
\text { antibodies. After incubation } \\
\text { with BoNT-containing } \\
\text { samples, the detection is } \\
\text { performed by adding } \\
\text { antibody-conjugated AuNPs. }\end{array}$ & $10 \mathrm{pg} / \mathrm{mL}$ & $\begin{array}{l}\text { BOTOX and Dysport } \\
\text { currently used in cosmetics } \\
\text { treatment }\end{array}$ & $\begin{array}{c}\text { Diluted in } 1 \mathrm{~mL} \text { of digestion buffer containing } 50 \mathrm{mM} \\
\text { HEPES (pH 7.4), } 5 \mathrm{mM} \mathrm{NaCl}, 0.1 \% \text { Tween } 20,0.05 \% \\
\text { ZnCl2, and } 2 \mathrm{mM} \text { DTT. }\end{array}$ & [95] \\
\hline Ricin & $\begin{array}{l}\text { Competitive colorimetric } \\
\text { LFIA }\end{array}$ & $0.005 \mu \mathrm{g} / \mathrm{mL}$ & $\begin{array}{c}\text { Eye make-up, shampoo, body } \\
\text { lotion }\end{array}$ & $\begin{array}{l}\text { Eye make-up samples were diluted 1:1 with } 10 \\
\text { mMPBS/0.1\% Tween-20/5\% non-fat milk (PBSTM) and } \\
\text { analyzed using the LFDs according to manufacturer's } \\
\text { instructions. The viscous shampoo and body lotion } \\
\text { samples were first diluted 1:9 and 1:19, respectively, } \\
\text { with PBS and then diluted 1:1 with PBSTM to generate } \\
\text { the 50\% PBSTM solution for analysis with the LFDs. }\end{array}$ & [97] \\
\hline
\end{tabular}


Table 1. Cont.

\begin{tabular}{|c|c|c|c|c|c|}
\hline Target Analyte & Immunological Method & Limit of Detection & Cosmetic Target & Sample Pre-Treatment & Ref. \\
\hline $\begin{array}{l}\text { Sialoglycoprotein typical } \\
\text { of edible bird's nest }\end{array}$ & $\begin{array}{c}\text { Competitive colorimetric } \\
\text { ELISA }\end{array}$ & $\begin{array}{l}\text { LoDs were } 10-18 \mu \mathrm{g} / \mathrm{g} \\
\text { depending on the } \\
\text { different cosmetic } \\
\text { matrices analyzed }\end{array}$ & $\begin{array}{c}\text { Facial mask, eye cream, } \\
\text { whitening serum, face cream, } \\
\text { essence }\end{array}$ & $\begin{array}{l}\text { The homogenized sample }(1 \mathrm{~g}) \text { was placed in a } 20 \mathrm{~mL} \\
\text { volumetric flask. The flask was then filled with PBS, } \\
\text { ultrasonicated for } 2 \text { min, and centrifuged at } 10,000 \mathrm{rpm} \\
\text { for } 1 \text { min. The aqueous phase was diluted to a suitable } \\
\text { concentration with PBS for ELISA. }\end{array}$ & [114] \\
\hline $\begin{array}{l}\text { Porcine gelatins, which is } \\
\text { a common adulterant } \\
\text { found in EBN used to } \\
\text { increase the net weight } \\
\text { before selling }\end{array}$ & $\begin{array}{c}\text { Competitive colorimetric } \\
\text { ELISA }\end{array}$ & $0.10 \mu \mathrm{g} / \mathrm{g}$ & Not tested on cosmetic matrix & - & [115] \\
\hline $\begin{array}{c}\text { Characteristic } \\
\text { glycoprotein of EBN }\end{array}$ & $\begin{array}{l}\text { Non-competitive colorimetric } \\
\text { LFIA (traditional colloidal } \\
\text { gold is replaced by the } \\
\text { nanocomposite } \mathrm{Au} @ \mathrm{SiO}_{2} \text { ) }\end{array}$ & $7.02 \mathrm{ng} / \mathrm{mL}$ & Not tested on cosmetic matrix & & [116] \\
\hline
\end{tabular}


Author Contributions: Conceptualization, M.Z. and M.M.C.; writing-original draft preparation, M.M.C. and M.Z.; writing-review and editing, D.C., M.G., E.M., A.M., J.F., M.M., S.M. and L.E.; Supervision, L.E. All authors have read and agreed to the published version of the manuscript.

Funding: This research received no external funding.

Informed Consent Statement: Not applicable.

Conflicts of Interest: The authors declare no conflict of interest.

\section{References}

1. Dorato, S. General concepts: Current legislation on cosmetics in various countries. In Analysis of Cosmetic Products, 2nd ed.; Salvador, A., Chisvert, A., Eds.; Elsevier Science B.V.: Amsterdam, The Netherlands, 2018; pp. 3-37.

2. Mildau, G. General review of official methods of analysis of cosmetics. In Analysis of Cosmetic Products, 2nd ed.; Salvador, A., Chisvert, A., Eds.; Elsevier Science B.V.: Amsterdam, The Netherlands, 2018; pp. 67-83.

3. Mitsui, T. Introduction. In New Cosmetic Science, 1st ed.; Mitsui, T., Ed.; Elsevier Science B.V.: Amsterdam, The Netherlands, 1997; pp. 3-7.

4. Chiari, B.G.; Almeida, M.G.J.; Corrêa, M.A.; Isaac, V.L.B. Cosmetics' quality control. In Latest Research into Quality Control, 1st ed.; Akyar, I., Ed.; InTech: Rijeka, Croatia, 2012; pp. 337-364.

5. Celeiro, M.; Garcia-Jares, C.; Llompart, M.; Lores, M. Recent Advances in Sample Preparation for Cosmetics and Personal Care Products Analysis. Molecules 2021, 26, 4900. [CrossRef] [PubMed]

6. Wu, L.; Li, G.; Xu, X.; Zhu, L.; Huang, R.; Chen, X. Application of nano-ELISA in food analysis: Recent advances and challenges. TrAC Trends Anal. Chem. 2019, 113, 140-156. [CrossRef]

7. Sengupta, P.; Wang, C.W.; Ma, Z.F. Enzyme-Linked Immunosorbent Assay (ELISA) Technique for Food Analysis. In Techniques to Measure Food Safety and Quality, 1st ed.; Khan, M.S., Rahman, M.S., Eds.; Springer: Cham, Switzerland, 2021 ; pp. 91-115.

8. Calabretta, M.M.; Zangheri, M.; Calabria, D.; Lopreside, A.; Montali, L.; Marchegiani, E.; Trozzi, I.; Guardigli, M.; Mirasoli, M.; Michelini, E. Paper-Based Immunosensors with Bio-Chemiluminescence Detection. Sensors 2021, 21, 4309. [CrossRef]

9. Calabria, D.; Calabretta, M.M.; Zangheri, M.; Marchegiani, E.; Trozzi, I.; Guardigli, M.; Michelini, E.; Di Nardo, F.; Anfossi, L.; Baggiani, C.; et al. Recent Advancements in Enzyme-Based Lateral Flow Immunoassays. Sensors 2021, 21, 3358. [CrossRef]

10. Xu, Y.; Liu, M.; Kong, N.; Liu, J. Lab-on-paper micro-and nano-analytical devices: Fabrication, modification, detection and emerging applications. Microchim. Acta 2016, 183, 1521-1542. [CrossRef]

11. Allergens in Cosmetics. Available online: https://www.fda.gov/cosmetics/cosmetic-ingredients/allergens-cosmetics (accessed on 12 August 2021).

12. Rey, A.; Corbi, E.; Pérès, C.; David, N. Determination of suspected fragrance allergens extended list by two-dimensional gas chromatography-mass spectrometry in ready-to-inject samples. J. Chromatogr. A 2015, 1404, 95-103. [CrossRef]

13. Tranchida, P.Q.; Maimone, M.; Franchina, F.A.; Bjerk, T.R.; Zini, C.A.; Purcaro, G.; Mondello, L. Four-stage (low-) flow modulation comprehensive gas chromatography quadrupole mass spectrometry for the determination of recently-highlighted cosmetic allergens. J. Chromatogr. A 2016, 1439, 144-151. [CrossRef]

14. Devos, C.; Ochiai, N.; Sasamoto, K.; Sandra, P.; David, F. Full evaporation dynamic headspace in combination with selectable onedimensional/two-dimensional gas chromatography-mass spectrometry for the determination of suspected fragrance allergens in cosmetic products. J. Chromatogr. A 2012, 1255, 207-215. [CrossRef] [PubMed]

15. Cordero, C.; Rubiolo, P.; Reichenbach, S.E.; Carretta, A.; Cobelli, L.; Giardina, M.; Bicchi, C. Method translation and full metadata transfer from thermal to differential flow modulated comprehensive two dimensional gas chromatography: Profiling of suspected fragrance allergens. J. Chromatogr. A 2017, 1480, 70-82. [CrossRef]

16. Celeiro, M.; Lamas, J.P.; Vila, M.; Garcia-Jares, C.; Homem, V.; Ratola, N.; Llompart, M. Determination of multiclass personal care products in continental waters by solid-phase microextraction followed by gas chromatography-tandem mass spectrometry. $J$. Chromatogr. A 2019, 1607, 460398. [CrossRef]

17. Desmedt, B.; Canfyn, M.; Pype, M.; Baudewyns, S.; Hanot, V.; Courselle, P.; Deconinck, E. HS-GC-MS method for the analysis of fragrance allergens in complex cosmetic matrices. Talanta 2015, 131, 444-451. [CrossRef] [PubMed]

18. Pérez-Outeiral, J.; Elcoroaristizabal, S.; Amigo, J.M.; Vidal, M. Development and validation of a method for the determination of regulated fragrance allergens by High-Performance Liquid Chromatography and parallel factor analysis 2. J. Chromatogr. A 2017, 1526, 82-92. [CrossRef]

19. Food Allergens Reliable Analytical Solutions for Your Allergen Management. Available online: https://food.r-biopharm.com/ analytes/food-allergens/ (accessed on 12 August 2021).

20. Ross, G.M.; Bremer, M.G.; Nielen, M.W. Consumer-friendly food allergen detection: Moving towards smartphone-based immunoassays. Anal. Bioanal. Chem. 2018, 410, 5353-5371. [CrossRef] [PubMed]

21. Ross, G.; Salentijn, G.I.; Nielen, M.W. A critical comparison between flow-through and lateral flow immunoassay formats for visual and smartphone-based multiplex allergen detection. Biosensors 2019, 9, 143. [CrossRef] [PubMed]

22. Fast and Reliable Test Kits for Food Allergen Detection. Available online: https://www.romerlabs.com/en/products/test-kits/ food-allergen-test-kits/ (accessed on 12 August 2021). 
23. $3 \mathrm{M}^{\mathrm{TM}}$ Allergen Protein ELISA Kit. Available online: https://www.3m.com/3M/en_US/p/d/b5005041032/ (accessed on 12 August 2021).

24. AlerTox ELISA. Available online: https://www.hygiena.com/food-safety-solutions/allergen-detection/alertox-elisa/ (accessed on 12 August 2021).

25. Duffort, O.A.; Polo, F.; Lombardero, M.; Díaz-Perales, A.; Sánchez-Monge, R.; García-Casado, G.; Barber, D. Immunoassay to quantify the major peach allergen Pru $\mathrm{p} 3$ in foodstuffs. Differential allergen release and stability under physiological conditions. J. Agric. Food Chem. 2002, 50, 7738-7741. [CrossRef]

26. Ashley, J.; D'Aurelio, R.; Piekarska, M.; Temblay, J.; Pleasants, M.; Trinh, L.; Tothill, I.E. Development of a $\beta$-Lactoglobulin sensor based on SPR for milk allergens detection. Biosensors 2018, 8, 32. [CrossRef] [PubMed]

27. Sollid, L.M. Coeliac disease: Dissecting a complex inflammatory disorder. Nat. Rev. Immunol. 2002, 2, 647-655. [CrossRef]

28. Battais, F.; Richard, C.; Jacquenet, S.; Denery-Papini, S.; Moneret-Vautrin, D.A. Wheat Grain Allergies: An Update on Wheat Allergens. Eur. Ann. Allergy Clin. Immunol. 2008, 40, 67-76.

29. Battais, F.; Courcoux, P.; Popineau, Y.; Kanny, G.; Moneret-Vautrin, D.-A.; Denery-Papini, S. Food Allergy to Wheat: Differences in Immunoglobulin E-Binding Proteins as a Function of Age or Symptoms. J. Cereal Sci. 2005, 42, 109-117. [CrossRef]

30. Mäki, M.; Collin, P. Coeliac disease. The lancet 1997, 349(9067), 1755-1759. [CrossRef]

31. Sharma, G.M.; Rallabhandi, P.; Williams, K.M.; Herrmann, M.; Sadrieh, N. Gluten quantitation in cosmetic products by enzymelinked immunosorbent assay. J. AOAC Int. 2016, 99, 586-590. [CrossRef]

32. Tranquet, O.; Lupi, R.; Echasserieau-Laporte, V.; Pietri, M.; Larré, C.; Denery-Papini, S. Characterization of antibodies and development of an indirect competitive immunoassay for detection of deamidated gluten. J. Agric. Food Chem. 2015, 63, 5403-5409. [CrossRef]

33. Available online: https://ec.europa.eu/growth/sectors/cosmetics/legislation_en (accessed on 12 August 2021).

34. Zhang, Y.; Xie, S.S.; Wu, Y.C.; Liang, Q.W.; Xie, X.T.; Luo, Z.H.; Liu, M.S. Research progress of detection technology for illegal addition of prohibited substances in cosmetics. In IOP Conference Series: Earth and Environmental Science; IOP Publishing: Bristol, UK, 2020; Volume 559, p. 012030.

35. Denver, N.; Khan, S.; Homer, N.Z.; MacLean, M.R.; Andrew, R. Current strategies for quantification of estrogens in clinical research. J. Steroid Biochem. Mol. Biol. 2019, 192, 105373. [CrossRef]

36. Tian, W.; Wang, L.; Lei, H.; Sun, Y.; Xiao, Z. Antibody production and application for immunoassay development of environmental hormones: A review. Chem. Biol. Technol. Agric. 2018, 5, 1-12. [CrossRef]

37. Liu, A.; Anfossi, L.; Shen, L.; Li, C.; Wang, X. Non-competitive immunoassay for low-molecular-weight contaminant detection in food, feed and agricultural products: A mini-review. Trends Food Sci. Technol. 2018, 71, 181-187. [CrossRef]

38. Wang, M.; Guo, L.; Yu, M.; Zhao, H. The application of a lateral flow immunographic assay to rapidly test for dexamethasone in commercial facial masks. Anal. Bioanal. Chem. 2019, 411, 5703-5710. [CrossRef] [PubMed]

39. Safety and Technical Standard for Cosmetics. Available online: http:/ /www.sesec.eu/app/uploads/2016/02/Cosmetics-Safetyand-Technical-Standards-2015-Version-Foreword-and-summary.pdf (accessed on 10 October 2021).

40. UNION, P. Regulation (EC) No 1223/2009 of the European parliament and of the council. Off. J. Eur. Union L 2009, $342,59$.

41. Zhang, S.; Yao, T.; Wang, S.; Feng, R.; Chen, L.; Zhu, V.; Yang, G. Upconversion luminescence nanoparticles-based immunochromatographic assay for quantitative detection of triamcinolone acetonide in cosmetics. Spectrochim. Acta Part A Mol. Biomol. Spectrosc. 2019, 214, 302-308. [CrossRef]

42. Yu, H.Y.; Liao, H.M. Triamcinolone permeation from different liposome formulations through rat skin in vitro. Int. J. Pharm. 1996, 127, 1-7. [CrossRef]

43. Matysova, L.; Hajkova, R.; Šícha, J.; Solich, P. Determination of methylparaben, propylparaben, triamcinolone acetonide and its degradation product in a topical cream by RP-HPLC. Anal. Bioanal. Chem. 2003, 376, 440-443. [CrossRef] [PubMed]

44. Jin, P.; Liang, X.; Wu, X.; He, X.; Kuang, Y.; Hu, X. Screening and quantification of 18 glucocorticoid adulterants from herbal pharmaceuticals and health foods by HPLC and confirmed by LC-Q-TOF-MS/MS. Food Addit. Contam. Part A 2018, 35, 10-19. [CrossRef] [PubMed]

45. Barré, F.P.; Flinders, B.; Garcia, J.P.; Jansen, I.; Huizing, L.R.; Porta, T.; Cillero-Pastor, B. Derivatization strategies for the detection of triamcinolone acetonide in cartilage by using matrix-assisted laser desorption/ionization mass spectrometry imaging. Anal. Chem. 2016, 88, 12051-12059. [CrossRef] [PubMed]

46. Nam, Y.S.; Kwon, I.K.; Lee, Y.; Lee, K.B. Quantitative monitoring of corticosteroids in cosmetic products manufactured in Korea using LC-MS/MS. Forensic Sci. Int. 2012, 220, e23-e28. [CrossRef]

47. Malone, E.M.; Elliott, C.T.; Kennedy, D.G.; Regan, L. Screening and quantitative confirmatory method for the analysis of glucocorticoids in bovine milk using liquid chromatography-tandem mass spectrometry. J. AOAC Int. 2010, 93, 1656-1665. [CrossRef]

48. Cui, X.; Wu, P.; Lai, D.; Zheng, S.; Chen, Y.; Eremin, S.A.; Zhao, S. Development of a highly specific fluorescence immunoassay for detection of diisobutyl phthalate in edible oil samples. J. Agric. Food Chem. 2015, 63, 9372-9378. [CrossRef]

49. Zhang, M.; Yu, X.; Wang, Y.; Hu, Y.; Liu, S. A highly sensitive indirect competitive enzyme-linked immunosorbent assay (ic-ELISA) by antigen coating for diethyl phthalate analysis in foods. Food Anal. Methods 2013, 6, 1223-1228. [CrossRef]

50. Tang, M.; Wu, Y.; Deng, D.; Wei, J.; Zhang, J.; Yang, D.; Li, G. Development of an optical fiber immunosensor for the rapid and sensitive detection of phthalate esters. Sens. Actuators B Chem. 2018, 258, 304-312. [CrossRef] 
51. Zhang, M.; Liu, S.; Zhuang, H.; Hu, Y. Determination of dimethyl phthalate in environment water samples by a highly sensitive indirect competitive ELISA. Appl. Biochem. Biotechnol. 2012, 166, 436-445. [CrossRef]

52. Chen, Y.; He, Q.; Shen, D.; Jiang, Z.; Eremin, S.A.; Zhao, S. Fluorescence polarization immunoassay based on a new monoclonal antibody for the detection of the Diisobutyl phthalate in Yoghurt. Food Control 2019, 105, 38-44. [CrossRef]

53. He, F.; Tian, Y.; Xu, Z.; Luo, L.; Yang, J.; Wang, H.; Shen, Y. Development of an immunochromatographic assay as a screen for detection of total phthalate acid esters in cooking oil. J. Toxicol. Environ. Health 2019, 81, 80-88. [CrossRef]

54. Zhang, M.C.; Wang, Q.E.; Zhuang, H.S. A novel competitive fluorescence immunoassay for the determination of dibutyl phthalate. Anal. Bioanal. Chem. 2006, 386, 1401-1406. [CrossRef]

55. Zhang, M.; Cong, Y.; Sheng, Y.; Liu, B. A direct competitive enzyme-linked immunosorbent assay by antibody coated for diethyl phthalate analysis. Anal. Biochem. 2010, 406, 24-28. [CrossRef]

56. Zhang, M.; Hu, Y.; Liu, S.; Cong, Y.; Liu, B.; Wang, L. Rapid monitoring of dipropyl phthalate in food samples using a chemiluminescent enzyme immunoassay. Food Anal. Methods 2012, 5, 1105-1113. [CrossRef]

57. Gimeno, P.; Maggio, A.F.; Bousquet, C.; Quoirez, A.; Civade, C.; Bonnet, P.A. Analytical method for the identification and assay of 12 phthalates in cosmetic products: Application of the ISO 12787 international standard "Cosmetics-Analytical methodsValidation criteria for analytical results using chromatographic techniques". J. Chromatogr. A 2012, 1253, 144-153. [CrossRef] [PubMed]

58. Liu, L.; Wang, Z.; Zhao, S.; Duan, J.; Tao, H.; Wang, W.; Liu, S. Determination of total phthalate in cosmetics using a simple three-phase sample preparation method. Anal. Bioanal. Chem. 2018, 410, 1323-1331. [CrossRef] [PubMed]

59. Wei, C.; Ding, S.; You, H.; Zhang, Y.; Wang, Y.; Yang, X.; Yuan, J. An immunoassay for dibutyl phthalate based on direct hapten linkage to the polystyrene surface of microtiter plates. PLoS ONE 2011, 6, e29196. [CrossRef]

60. Lv, B.; Jiang, Q.; Zhu, C. A review of heavy metals immunoassay detection. Adv. J. Food Sci. Technol. 2015, 8, 559-565. [CrossRef]

61. Su, S.P.; Xu, F.; Cao, H.; Zhai, M.S.; Yu, J.S. Perspective in the rapid methods for the detection of heavy metals. Appl. Chem. Ind. 2013, 42, 355-359.

62. Verma, N.; Singh, M. Biosensors for heavy metals. Biometals 2005, 18, 121-129. [CrossRef] [PubMed]

63. Khosraviani, M.; Pavlov, A.R.; Flowers, G.C.; Blake, D.A. Detection of heavy metals by immunoassay: Optimization and validation of a rapid, portable assay for ionic cadmium. Environ. Sci. Technol. 1998, 32, 137-142. [CrossRef]

64. Chakrabarti, P.; Hatcher, F.M.; Blake, R.C.; Ladd, P.A.; Blake, D.A. Enzyme immunoassay to determine heavy metals using antibodies to specific metal-EDTA complexes: Optimization and validation of an immunoassay for soluble indium. Anal. Biochem. 1994, 217, 70-75. [CrossRef] [PubMed]

65. Ouyang, H.; Shu, Q.; Wang, W.; Wang, Z.; Yang, S.; Wang, L.; Fu, Z. An ultra-facile and label-free immunoassay strategy for detection of copper (II) utilizing chemiluminescence self-enhancement of $\mathrm{Cu}$ (II)-ethylenediaminetetraacetate chelate. Biosens. Bioelectron. 2016, 85, 157-163. [CrossRef]

66. Wang, Y.; Yang, H.; Pschenitza, M.; Niessner, R.; Li, Y.; Knopp, D.; Deng, A. Highly sensitive and specific determination of mercury (II) ion in water, food and cosmetic samples with an ELISA based on a novel monoclonal antibody. Anal. Bioanal. Chem. 2012, 403, 2519-2528. [CrossRef]

67. Zhang, J.; Wang, M.; Yao, X.; Deng, A.; Li, J. Highly sensitive electroluminescence immunoassay for Hg (II) ions based on the use of CdSe quantum dots, the methylmercury-6-mercaptonicotinic acid-ovalbumin conjugate, and a specific monoclonal antibody. Microchim. Acta 2015, 182, 469-477. [CrossRef]

68. Michalek, I.M.; John, S.M.; Caetano dos Santos, F.L. Microbiological contamination of cosmetic products-observations from Europe, 2005-2018. J. Eur. Acad. Dermatol. Venereol. 2019, 33, 2151-2157. [CrossRef]

69. Becks, V.; Lorenzoni, N. Pseudomonas aeruginosa outbreak in a neonatal intensive care unit: A possible link to contaminated hand lotion. Am. J. Infect. Control 1995, 23, 396-398. [CrossRef]

70. Behravan, J.; Bazzaz, F.; Malaekeh, P. Survey of bacteriological contamination of cosmetic creams in Iran (2000). Int. J. Dermatol. 2005, 44, 482-485. [CrossRef] [PubMed]

71. Campana, R.; Scesa, C.; Patrone, V.; Vittoria, E.; Baffone, W. Microbiological study of cosmetic products during their use by consumers: Health risk and efficacy of preservative systems. Lett. Appl. Microbiol. 2006, 43, 301-306. [CrossRef] [PubMed]

72. Moore, I. Manufacturing Cosmetic Ingredients according to Good Manufacturing Practice Principles. In Global Regulatory Issues for the Cosmetics Industry; William Andrew Publishing: Norwich, NY, USA, 2009; pp. 79-92.

73. US Pharmacopeial Convention. USP: National Formulary; USP: Rockville, MD, USA, 2006.

74. European Pharmacopeia Secretariat. European Pharmacopeia; European Pharmacopeia Secretariat: Strasbourg, France, 1998.

75. Okeke, I.N.; Lamikanra, A. Bacteriological quality of skin-moisturizing creams and lotions distributed in a tropical developing country. J. Appl. Bacteriol. 2001, 91, 922-928. [CrossRef]

76. Alamer, S.; Eissa, S.; Chinnappan, R.; Herron, P.; Zourob, M. Rapid colorimetric lactoferrin-based sandwich immunoassay on cotton swabs for the detection of foodborne pathogenic bacteria. Talanta 2018, 185, 275-280. [CrossRef] [PubMed]

77. Cheng, N.; Song, Y.; Zeinhom, M.M.; Chang, Y.C.; Sheng, L.; Li, H.; Lin, Y. Nanozyme-mediated dual immunoassay integrated with smartphone for use in simultaneous detection of pathogens. ACS Appl. Mater. Interfaces 2017, 9, 40671-40680. [CrossRef]

78. Xue, L.; Huang, F.; Hao, L.; Cai, G.; Zheng, L.; Li, Y.; Lin, J. A sensitive immunoassay for simultaneous detection of foodborne pathogens using $\mathrm{MnO} 2$ nanoflowers-assisted loading and release of quantum dots. Food Chem. 2020, 322, 126719. [CrossRef] 
79. Wang, Z.; Yao, X.; Zhang, Y.; Wang, R.; Ji, Y.; Sun, J.; Wang, J. Functional nanozyme mediated multi-readout and label-free lateral flow immunoassay for rapid detection of Escherichia coli O157: H7. Food Chem. 2020, 329, 127224. [CrossRef]

80. English, D.; Scalici, C.; Hamilton, J.; Destro, C.; Jimenez, L. Evaluation of the TECRA ${ }^{\mathrm{TM}}$ visual immunoassay for detecting Staphylococcus aureus in cosmetic/pharmaceutical raw materials and finished products. J. Rapid Methods Autom. Microbiol. 1999, 7, 193-203. [CrossRef]

81. Xie, W.; Chen, C.; Huang, Y.; Fu, H. Determination of chloramphenicol in cosmetics by GC-MS. Chin. J. Chromatogr. 2006, 24, 659.

82. Wang, P.; Li, J.; Zheng, H. Simultaneous determination of seven sulfonamides and metronidazole and chloramphenicol in cosmetics by high performance liquid chromatography. Chin. J. Chromatogr. 2007, 25, 743-746.

83. Aiassa, V.; Zoppi, A.; Becerra, M.C.; Albesa, I.; Longhi, M.R. Enhanced inhibition of bacterial biofilm formation and reduced leukocyte toxicity by chloramphenicol: $\beta$-cyclodextrin: N-acetylcysteine complex. Carbohydr. Polym. 2016, 152, 672-678. [CrossRef] [PubMed]

84. Lofrano, G.; Libralato, G.; Adinolfi, R.; Siciliano, A.; Iannece, P.; Guida, M.; Carotenuto, M. Photocatalytic degradation of the antibiotic chloramphenicol and effluent toxicity effects. Ecotoxicol. Environ. Saf. 2016, 123, 65-71. [CrossRef]

85. US FDA. Code of Federal Regulations. 556.283 Florfenicol; US Food and Drug Administration: Washington, DC, USA, 2002.

86. European Union. Commission Regulation (EU) No 37/2010 of 22 December 2009 on pharmacologically active substances and their classification regarding maximum residue limits in foodstuffs of animal origin. Off. J. Eur. Union 2010, L15, 1-32.

87. The Japan Food Chemical Research Foundation. Japan Positive List System. Available online: https://www.ffcr.or.jp/en/ zanryu / the-japanese-positive/ the-japanese-positive-list-system-for-agricultural-chemical-residues-in-foods-enforcement-onmay-29-.html (accessed on 12 August 2021).

88. Ministry of Agriculture. No. 235 Bulletin of the Ministry of Agriculture of the People's Republic of China; Ministry of Agriculture: Pechino, China, 2002.

89. Vosough, M.; Esfahani, H.M. Fast HPLC-DAD quantification procedure for selected sulfonamids, metronidazole and chloramphenicol in wastewaters using second-order calibration based on MCR-ALS. Talanta 2013, 113, 68-75. [CrossRef] [PubMed]

90. Rimkus, G.G.; Hoffmann, D. Enantioselective analysis of chloramphenicol residues in honey samples by chiral LC-MS/MS and results of a honey survey. Food Addit. Contam. Part A 2017, 34, 950-961. [CrossRef] [PubMed]

91. Fedeniuk, R.W.; Mizuno, M.; Neiser, C.; O’Byrne, C. Development of LC-MS/MS methodology for the detection/determination and confirmation of chloramphenicol, chloramphenicol 3-O- $\beta$-d-glucuronide, florfenicol, florfenicol amine and thiamphenicol residues in bovine, equine and porcine liver. J. Chromatogr. B 2015, 991, 68-78. [CrossRef]

92. Li, Q.; Zhu, R.; Li, J.; Wang, X.; Xu, L.; Li, Y.; Li, P. Highly Specific Chemiluminescence Immunoassay for the Determination of Chloramphenicol in Cosmetics. Int. J. Anal. Chem. 2019, 2019, 7131907. [CrossRef] [PubMed]

93. Xun, Y.P.; Yan, H.; Liu, J.; Shi, L.L.; Chen, P.; Du, H.W. Development of a high-throughput Immunoassay for rapid detection of multiple antibiotic residues in cosmetics. In Advanced Materials Research; Tang, Y., Xu, Q., Min, Y., Eds.; Trans Tech Publications Ltd.: Bach, Switzerland, 2015; Volume 1073, pp. 357-361.

94. Zangheri, M.; Di Nardo, F.; Calabria, D.; Marchegiani, E.; Anfossi, L.; Guardigli, M.; Roda, A. Smartphone biosensor for point-of-need chemiluminescence detection of ochratoxin A in wine and coffee. Anal. Chim. Acta 2021, 1163, 338515. [CrossRef]

95. Le Loir, Y.; Baron, F.; Gautier, M. [i] Staphylococcus aureus [/i] and food poisoning. Genet. Mol. Res. GMR 2003, $2,63-76$.

96. Cheng, H.P.; Chuang, H.S. Rapid and Sensitive Nano-Immunosensors for Botulinum. ACS Sens. 2019, 4, 1754-1760. [CrossRef]

97. Dayan-Kenigsberg, J.; Bertocchi, A.; Garber, E.A. Rapid detection of ricin in cosmetics and elimination of artifacts associated with wheat lectin. J. Immunol. Methods 2008, 336, 251-254. [CrossRef] [PubMed]

98. Sasikumar, B.; Swetha, V.P.; Parvathy, V.A.; Sheeja, T.E. Advances in adulteration and authenticity testing of herbs and spices. In Advances in Food Authenticity Testing; Downey, G., Ed.; Woodhead Publishing: Sawston, UK, 2016; pp. 585-624.

99. Mandli, J.; Fatimi, I.E.; Seddaoui, N.; Amine, A. Enzyme immunoassay (ELISA/immunosensor) for a sensitive detection of pork adulteration in meat. Food Chem. 2018, 255, 380-389. [CrossRef]

100. Chávez, N.A.; Salinas, E.; Jauregui, J.; Palomares, L.A.; Macias, K. Detection of bovine milk adulterated with cheese whey by western blot immunoassay. Food Agric. Immunol. 2008, 19, 265-272. [CrossRef]

101. Sharma, R.; Verma, A.; Shinde, N.; Mann, B.; Gandhi, K.; Wichers, J.H.; van Amerongen, A. Adulteration of cow's milk with buffalo's milk detected by an on-site carbon nanoparticles-based lateral flow immunoassay. Food Chem. 2021, 351, 129311. [CrossRef]

102. Pizzo, J.S.; Galuch, M.B.; Santos, P.D.; Santos, O.O.; Visentainer, L.; Eberlin, M.N.; Visentainer, J.V. Assessment of adulteration of cosmetics based on vegetable oils by GC-FID and lipid profile using direct infusion electrospray ionization mass spectrometry (ESI-MS). J. Braz. Chem. Soc. 2018, 29, 2457-2465. [CrossRef]

103. Paikrao, H.M.; Shende, V.A. Investigation of adulteration in kumkum. Mater. Today Proc. 2020, 29, 801-806. [CrossRef]

104. Lee, T.H.; Wani, W.A.; Koay, Y.S.; Kavita, S.; Tan, E.T.T.; Shreaz, S. Recent advances in the identification and authentication methods of edible bird's nest. Food Res. Int. 2017, 100 Pt 1, 14-27. [CrossRef] [PubMed]

105. Kim, K.C.; Kang, K.A.; Lim, C.M.; Park, J.H.; Jung, K.S.; Hyun, J.W. Water extract of edible bird's nest attenuated the oxidative stress-induced matrix metalloproteinase- 1 by regulating the mitogen-activated protein kinase and activator protein-1 pathway in human keratinocytes. J. Korean Soc. Appl. Biol. Chem. 2012, 55, 347-354. [CrossRef] 
106. Vimala, B.; Hussain, H.; Nazaimoon, W.M.W. Effects of edible bird's nest on tumour necrosis factor-alpha secretion, nitric oxide production and cell viability of lipopolysaccharide-stimulated RAW 264.7 macrophages. Food Agric. Immunol. 2012, $23,303-314$. [CrossRef]

107. Xie, Y.; Zeng, H.; Huang, Z.; Xu, H.; Fan, Q.; Zhang, Y.; Zheng, B. Effect of maternal administration of edible bird's nest on the learning and memory abilities of suckling offspring in mice. Neural Plast. 2018, 2018, 7697261. [CrossRef]

108. Ma, F.; Liu, D. Sketch of the edible bird's nest and its important bioactivities. Food Res. Int. 2012, 48, 559-567. [CrossRef]

109. Yang, M.; Cheung, S.H.; Li, S.C.; Cheung, H.Y. Establishment of a holistic and scientific protocol for the authentication and quality assurance of edible bird's nest. Food Chem. 2014, 151, 271-278. [CrossRef]

110. Seow, E.K.; Ibrahim, B.; Muhammad, S.A.; Lee, L.H.; Cheng, L.H. Differentiation between house and cave edible bird's nests by chemometric analysis of amino acid composition data. LWT-Food Sci. Technol. 2016, 65, 428-435. [CrossRef]

111. Kong, H.K.; Wong, K.H.; Lo, S.C. Identification of peptides released from hot water insoluble fraction of edible bird's nest under simulated gastro-intestinal conditions. Food Res. Int. 2016, 85, 19-25. [CrossRef]

112. Guo, L.; Wu, Y.; Liu, M.; Wang, B.; Ge, Y.; Chen, Y. Authentication of edible bird's nests by TaqMan-based real-time PCR. Food Control 2014, 44, 220-226. [CrossRef]

113. Quek, M.C.; Chin, N.L.; Tan, S.W.; Yusof, Y.A.; Law, C.L. Molecular identification of species and production origins of edible bird's nest using FINS and SYBR green I based real-time PCR. Food Control 2018, 84, 118-127. [CrossRef]

114. Zhang, S.; Lai, X.; Liu, X.; Li, Y.; Li, B.; Huang, X.; Yang, G. Competitive enzyme-linked immunoassay for sialoglycoprotein of edible bird's nest in food and cosmetics. J. Agric. Food Chem. 2012, 60, 3580-3585. [CrossRef]

115. Tukiran, N.A.; Ismail, A.; Mustafa, S.; Hamid, M. Enzyme immunoassay for the detection of porcine gelatine in edible bird's nests. Food Addit. Contam. Part A 2015, 32, 1023-1028. [CrossRef] [PubMed]

116. Xu, H.; Zheng, L.; Xie, Y.; Zeng, H.; Fan, Q.; Zheng, B.; Zhang, Y. Identification and determination of glycoprotein of edible bird's nest by nanocomposites based lateral flow immunoassay. Food Control 2019, 102, 214-220. [CrossRef] 